\title{
Parametry konstrukcyjne zestawów kołowych oraz ich wpływ na bezpieczeństwo jazdy
}

\begin{abstract}
$W$ artykule przedstawiono stan normalizacyjny zestawów kołowych, które należq do najbardziej obciqżonych czéści w kolejnictwie. Omówiono znaczenie parametru $q_{R}$, biorac pod uwage jego wpływ jak bezpieczeństwo jazdy, konieczność napraw oraz konserwacji. Przedstawiono dopuszczalne wymiary kresowe parametru z uwagi na bezpieczeństwo eksploatacyjne, które sq zdefiniowane $w$ kartach UIC, normach europejskich oraz przepisach TSI.
\end{abstract}

\section{WSTĘP}

Zestawy kołowe należą do najbardziej obciążonych podzespołów układu biegowego. Na zestaw kołowy, wchodzący w skład układu biegowego pojazdu szynowego działają siły statyczne nadzwyczajne, siły dynamiczne oraz siły udarowe, które są wynikiem oddziaływania w układzie koło-szyna.

Zestaw kołowy spełniać wymagania następujących norm europejskich z uwagi na kryteria wytrzymałości, konstrukcji, badań oraz obsługi i konserwacji musi:

- PN-EN 13103+A2:2012 [3] w zakresie metodyki obliczeń wytrzymałości osi tocznych,

- PN-EN 13104+A2:2011 [4] w zakresie metodyki obliczeń wytrzymałości osi napędnych,

- PN-EN 13260+A1:2011 [5] w zakresie wymagań i badań dotyczących montażu zestawów kołowych,

- PN-EN 13261+A1:2011[6] w zakresie wymagań i badań dotyczących, produkowanych osi,

- PN-EN 13262+A2:2011[7] w zakresie wymagań i badań dotyczących kół, produkowanych osi,

- PN-EN 13715+A1:2011 [8] w zakresie zarysów zewnętrznych kół,

- PN-EN 15313:2010 [10] w zakresie wymagań dotyczących obsługi i eksploatacji zestawów kołowych oraz kart UIC,

- karty UIC 510-2 [11] w zakresie wymiarów koła i zarysów zewnętrznych.

Zestawy kołowe dzielą się na dwie zasadnicze grupy:

- zestawy kołowe trakcyjne (napędne)

- zestawy kołowe toczne.

Aby zagwarantować bezpieczną jazdę $w$ torze, koła i zestaw kołowy muszą spełniać parametry geometryczne o wartościach, określonych przez przepisy. Jednym $\mathrm{z}$ takich parametrów jest wymiar stromości obrzeża, zwany $\mathrm{q}_{R}$ (niem. , $\mathrm{q}_{\mathrm{R}}$-Mass”, ang. , $\mathrm{q}_{\mathrm{R}}$-measure”).

\section{DEFINICJA WYMIARU STROMOŚCI OB.- RZEŻA}

Stromość obrzeża jest jednym z parametrów koła oraz zestawu kołowego, decydujących o bezpieczeństwie jazdy pojazdów szynowych. Wymiar stromości obrzeża $\mathrm{q}_{\mathrm{R}} \mathrm{W}$ poszczególnych stanach podają następujące przepisy:

$\Rightarrow$ w stanie nowym zgodnie z kartą UIC 510-2 [11]

$\Rightarrow$ w stanie nowym i zużytym instrukcja Mt 11 [15]

$\Rightarrow$ w stanie zużytym przepisy EBO dla DB AG [19]

$\Rightarrow \mathrm{w}$ stanie zużytym raport ORE/ERRI C70/Rp.RE/D [12] i ORE/ERRI C70/Rp.1/D [13]

$\Rightarrow$ przepisy CR TSI WAG „Wagony towarowe.” Przyjęte decyzją Komisji Europejskiej 2006/86/2009/107. Nowa wersja 2012 [17].

W miare przebiegu pojazdu następuje zużycie powierzchni tocznej koła oraz obrzeża. Zużycie powierzchni tocznej koła jest wynikiem działania sił pionowych działających na koło, które tworzą tzw. „elipsę styku”. Zużycie obrzeża jest wynikiem działania sił poprzecznych działających na koło na torze prostym w wyniku drgań poprzecznych oraz wężykowania zestawu kołowego, będących wynikiem prowadzenia zestawu kołowego w torze oraz poprzecznych nierówności toru. Maksymalne wartości sił poprzecznych występują na łuku, w związku z czym obrzeże zużywa się tam intensywniej. Jednym $z$ wymiarów charakteryzujących zarys zewnętrzny obrzeża jest tzw. wymiar $\mathrm{q}_{\mathrm{R}}$ określany jako „wymiar stromości obrzeża". W miarę zużycia wymiar $\mathrm{q}_{\mathrm{R}}$ zmienia się i może przyjmować minimalną wartości $\mathrm{q}_{\mathrm{R}}>6,5 \mathrm{~mm}$ dla ruchu pasażerskiego, zgodnie z instrukcją Mt 11 [15]. Takie samo kryterium jest przyjęte przez przepisy EBO dla kolei niemieckich DB AG i jest opatrzone komentarzem, że jest to „wartość wymiaru służącą do oceny 
zużycia obrzeża.” Instrukcja Mt 11 [15] podaje maksymalną wartość wymiaru $\mathrm{q}_{\mathrm{R}}=11,5^{+0,5} \mathrm{~mm}$ jako obowiązująca dla profilu nowego. W karcie UIC 5102 [11] p. 1.5 zamieszcza następujący zapis ,,wymiar $q_{R}$ mierzony na obrzeżu koła za pomoca sprawdzianu musi być większy lub równy $6,5 \mathrm{~mm}$, przy czym w strefie zewnętrznej powierzchni prowadzacej aż do 2 mm poniżej maksymalnej wysokości nie może występować żadne odsadzenie lub „zawalcowanie” . Wartość ta występuje jako podstawa do innych rozważań technicznych [1,2]. Wartość maksymalna wymiaru jest podana dla stanu nowego w karcie UIC 510-2 $\mathrm{q}_{\mathrm{R}}=10,794 \mathrm{~mm}$ [11]. Przepisy EBO nie podają maksymalnego dopuszczalnego wymiaru $\mathrm{q}_{\mathrm{R}}$.

Pomiar wymiaru $\mathrm{q}_{\mathrm{R}} \mathrm{W}$ trakcie eksploatacji został zalecony przez ORE/ERRI w wyniku prac badawczych opisanych w raportach C70/RE/D [12] oraz C70/RP1/D [13]. Pomiar wymiaru $\mathrm{q}_{\mathrm{R}}$ odbywa się na obrzeżu $10 \mathrm{~mm}$ powyżej powierzchni tocznej za pomocą sprawdzianu, przedstawionego na rys.1.

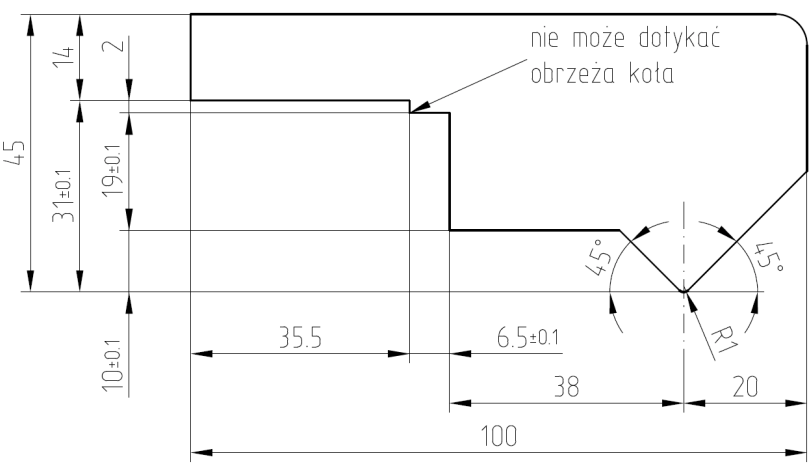

Rys.1. Szablon do pomiaru wymiaru $\mathrm{q}_{\mathrm{R}}$ na obrzeżu koła

Graficzne określenie parametru $\mathrm{q}_{\mathrm{R}}$ jest przedstawione na rys.2. Przypadek kwalifikacji obrzeża koła przy pomocy sprawdzianu $\mathrm{q}_{\mathrm{R}}$ jest przedstawiony odpowiednio na rys.3 i rys. 4 .

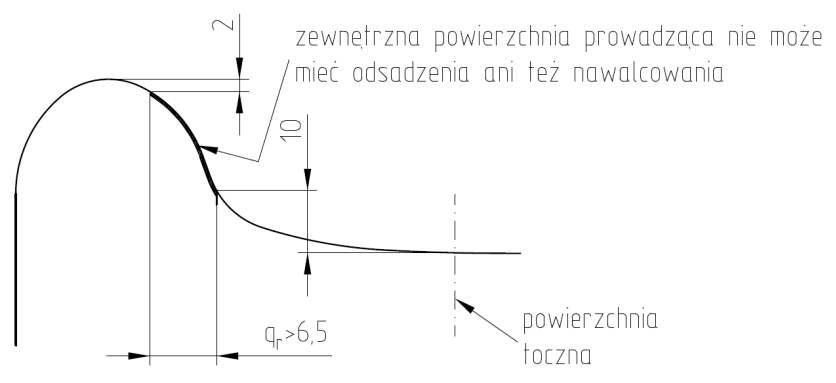

Rys.2. Graficzne określenie parametru stromości obrzeżą $q_{R}$

Przypadek pokazany na rys.3 wskazuje wyraźnie na brak spełnienia kryterium stromości obrzeża przy $\mathrm{q}_{\mathrm{R}} \leq 6,5 \mathrm{~mm}$, w związku z czym koła należy poddać zabiegowi „reprofilacji” (odtworzeniu profilu).

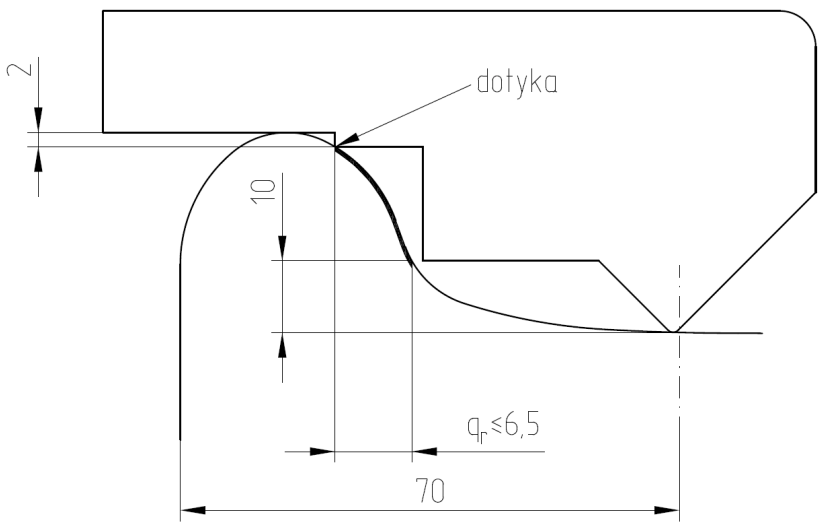

Rys.3. Pomiar wymiaru stromości obrzeża koła $\mathrm{q}_{\mathrm{R}}$ przy pomocy sprawdzianu (kwalifikacja negatywna)

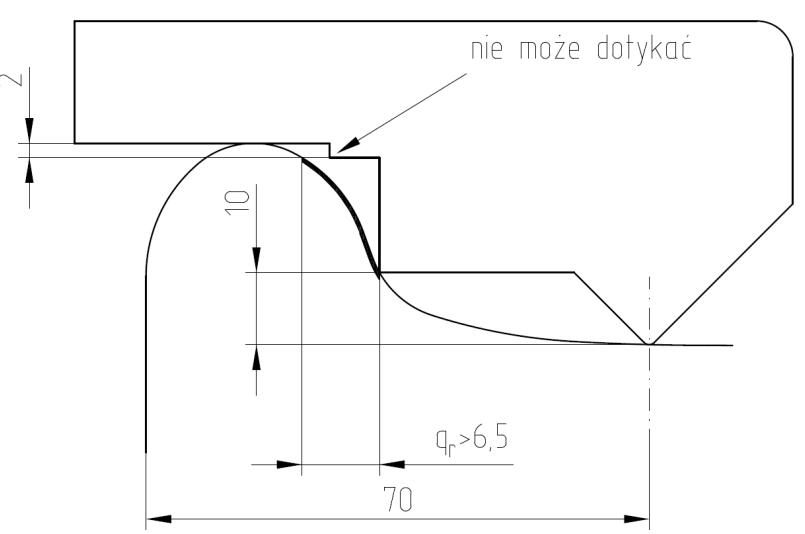

Rys.4. Pomiar wymiaru stromości obrzeża koła $\mathrm{q}_{\mathrm{R}}$ przy pomocy sprawdzianu (kwalifikacja pozytywna)

\section{ZNACZENIE PARAMETRU $q_{R} W$ TECHNICE KOLEJOWEJ}

Przypadek pokazany na rys. 4 wskazuje na spełnienie kryterium stromości obrzeża przy $\mathrm{q}_{\mathrm{R}}>6,5$ mm, w związku z czym koła można zakwalifikować do dalszej eksploatacji. Pomiary stromości obrzeża koła $\mathrm{q}_{\mathrm{R}}$ są związane ze zmieniającą się wartością tego wymiaru w trakcie eksploatacji. Na ogół bardziej niebezpieczny jest przypadek obrzeża z ostrym kształtem, przez który rozumie się obrzeże ze zwiększonym kątem pochylenia boku obrzeża tzn. ponad $70^{\circ}$.

Pomiar wymiaru $\mathrm{q}_{\mathrm{R}}$ obrzeża wieńca koła jest związany $z$ bezpieczeństwem przejazdu pojazdów szynowych przez zwrotnice w dwóch przypadkach:

- podczas przejazdu przez iglice zwrotnic, zwłaszcza kiedy występuje odstęp pomiędzy iglicą a opornicą o wymiarze maksymalnym $\mathrm{q}_{\varepsilon}=3,5 \mathrm{~mm}$ lub kiedy górna cześć iglicy jest uszkodzona oraz szyna oporowa są mocno zużyte na wysokości oraz $\mathrm{w}$ kierunku poprzecznym (rys.5)

- podczas nabiegania koła na krzyżownicę, kiedy ona jest uszkodzona lub nie jest ona wystarczająco zabezpieczona przez kierownicę. 
Stąd można wyciagnąć wniosek, że przy pomierzonej wartości $\mathrm{q}_{\mathrm{R}}=14 \mathrm{~mm}$ warunek przejazdu przez elementy zwrotnic jest na pewno spełniony. W przypadku kiedy $\mathrm{q}_{\mathrm{R}}$ przyjmuje wartości większe niż wynika to ze stanu nowego obrzeża wówczas można wnioskować o większym zużyciu powierzchni tocznej, aniżeli obrzeża, a jego wysokość powinna się zwiększać. Taki przypadek jest korzystny z punktu widzenia zużycia koła, gdyż zużycie obrzeża o $1 \mathrm{~mm}$ jest równe około $2,5 \mathrm{~mm}$ zużycia na powierzchni tocznej, co jest związane $\mathrm{z}$ trwałością koła oraz ewentualnymi „reprofilacjami” zarysu zewnętrznego wieńca koła.

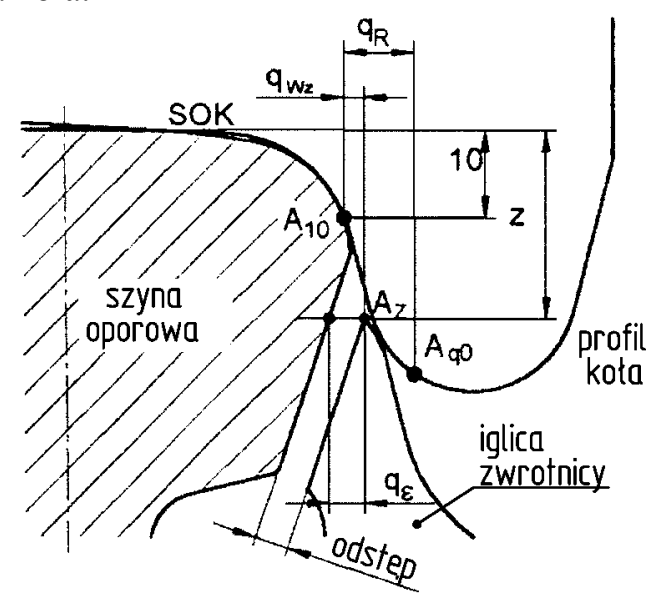

Rys.5. Współpraca szyny oporowej oraz iglicy zwrotnicy z kołem pojazdu (wymiary $\mathrm{q}_{\mathrm{R}} \mathrm{i} \mathrm{q}_{\varepsilon}$ ) wg [2]

Odstęp określany jako $\mathrm{q}_{\varepsilon}$ (niem. „Klaffmass”) jest odległością pomiędzy powierzchnią boczną iglicy zwrotnicy oraz szyny oporowej (niem. „Backenschiene"). Z uwagi na bezpieczeństwo przejazdu wymiar ten ustalono na poziomie $3 \mathrm{~mm}$. Usytuowanie zestawu kołowego na zwrotnicy jest pokazane na rys.6.
Objaśnienia pojęć na rys.6.:

$\mathrm{A}_{\mathrm{R}}$-odległość pomiędzy wewnętrznymi płaszczyznami czołowymi wieńców kół (niem. „Rückenabstand”)

$a_{R}$ - odległość pomiędzy krawędzią kierownicy i iglicy (niem., Stichweite")

a- szerokość uniesienia koła (niem.,, Radaufstandbreite")

b- szerokość wieńca koła (niem.,Radbreite”)

h- odległość pomiędzy wierzchołkiem iglicy a boczną powierzchnią szyny skrzydłowej (niem. „Herzstückrille")

L-odległość pomiędzy wewnętrzną powierzchnią płaszczyzną wieńca koła i punktem prowadnym na obrzeżu przeciwległego koła (niem.,Leitmass”)

1- odległość między krawędzie roboczą iglicy rozjaz$\mathrm{du}$, a krawędzią roboczą przeciwległej kierownicy (niem.,,Leitweite")

$\mathrm{q}_{\mathrm{R}}$ - parametr stromości obrzeża (niem.,, $\mathrm{q}_{\mathrm{R}}$-Mass") r- odległość pomiędzy boczną krawędzią kierownicy i boczną powierzchnią szyny jezdnej

$\mathrm{S}_{\mathrm{d}}$ - grubość obrzeża (niem.,,Spurkranzdicke”)

$\mathrm{S}_{\mathrm{m}^{-}}$szerokość prowadna zestawu kołowego (niem.,,Spurmass")

S-odległość pomiędzy płaszczyznami tocznymi kół (niem.,,Abstand der Laufkreisebenen”)

s-prześwit toru, szerokość toru (niem. „Spurweite”)

$\gamma$ - kąt pochylenia obrzeża (niem.

„Spurkranzflankenwinkel”)

Fahrschiene- szyna jezdna

Flügelschiene- szyna skrzydłowa

Herzstückspitze- iglica zwrotnicy

Laufkreisebenen- płaszczyzny okręgów tocznych

Messkreispunkt-punkt okręgu tocznego koła

Radaufstandbreite- szerokość „uniesienia koła”

Radlenker- kierownica

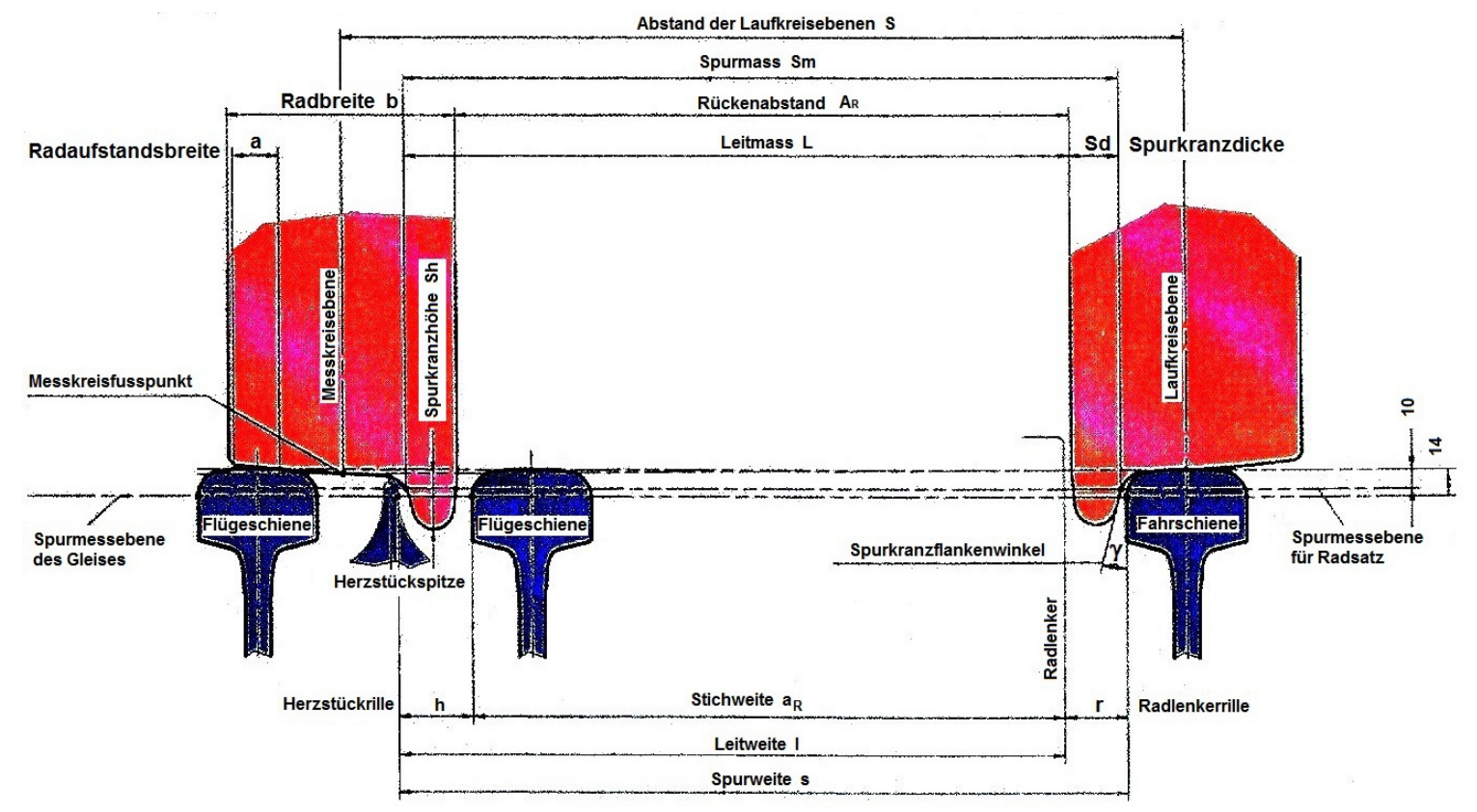

Rys.6. Usytuowanie zestawu kołowego na zwrotnicy-współpraca części zestawu kołowego z elementami zwrotnicy wg [1] 
Radlenkerrille- odległość pomiędzy krawędzią kierownicy i wewnętrzną krawędzią szyny

Spurmessebene des Gleises- płaszczyzna pomiarowa toru

Spurmessebene für Radsatz -płaszczyzna utworzona przez punkty prowadne kół zestawu kołowego

Większe wartości stromości obrzeża $\mathrm{q}_{\mathrm{R}}$ sięgające wartości $12,1 \mathrm{~mm}$ są znane $\mathrm{z}$ badań wagonów towarowych typu Fals na wózkach ze prowadzeniem wzdłużnym quasi-radialnym Y25OR (fr.orientable).

Wózek ten jest pokazany na rys.7, natomiast jego zawieszenie jest pokazane na rys.8.

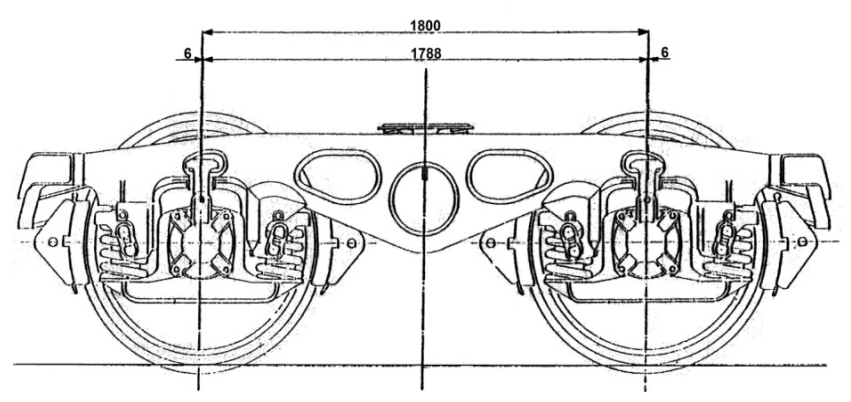

Rys.7. Wózek typu Y25OR, przeznaczony do wózków wagonów towarowych

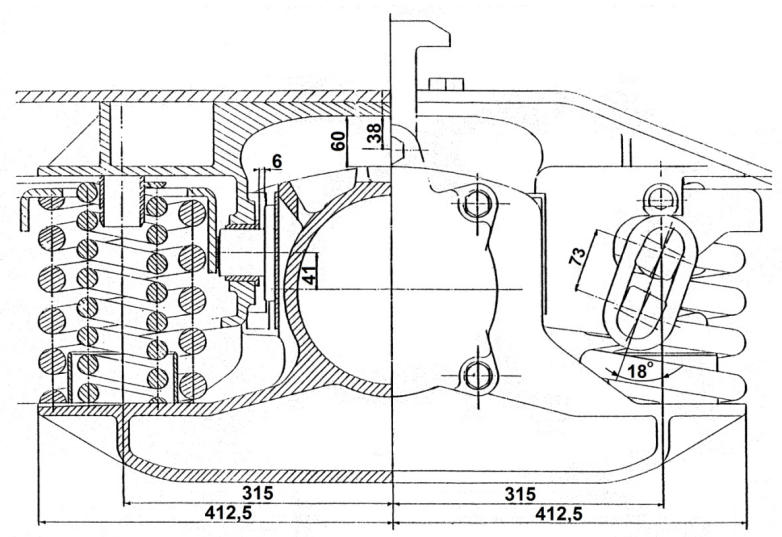

Rys.8. Zawieszenie pierwszego stopnia wózka Y25OR, przeznaczonego do wagonów towarowych

Wózki te posiadają luzy wzdłużne w prowadzeniu pierwszego stopnia, pomiędzy korpusem prowadnicy a korpusem maźnicy. Wyniki tych pomiarów zostały zawarte $\mathrm{w}$ raporcie z badań ORE/ERRI B12/Rp.56 (tablica 2), co zostało przedstawione w załączniku 11 [14]. Eksploatacja wagonów towarowych $\mathrm{z}$ wózkami Y25OR potwierdza, że radialne prowadzenie zestawów kołowych przyczynia się $\mathrm{w}$ dużej mierze do zwiększenia parametru $\mathrm{q}_{\mathrm{R}}$. Jak widać $\mathrm{z}$ zał.11 maksymalna wartość $\mathrm{q}_{\mathrm{R}}$ podczas badań wynosiła $12,2 \mathrm{~mm}$. $\mathrm{Z}$ przytoczonego fragmentu raportu ORE/ERRI B12 Rp.56 [14] zwiększona wartość $\mathrm{q}_{\mathrm{R}}$ na pewnym etapie badań nie powodowała jego dalszego zwiększenia. Zwiększone wartości parametru $\mathrm{q}_{\mathrm{R}} \mathrm{W}$ przypadku eksploatacji wagonów towarowych, wyposażonych w wózki Y25OR nie są żadnym zaskoczeniem pod względem technicznym. Wózki te posiadając luzy w kierunku wzdłużnym $\pm 6 \mathrm{~mm}$, przyczyniają się do quasi-radialnego ustawienia zestawów kołowych na łukach toru. Powoduje to zmniejszenie sił prowadzących (niem. „Führungskräfte”) oraz zmniejszenie kątów nabiegania obrzeży kół na szyny. Zmniejszenie sił prowadzących i kątów nabiegania powoduje z kolei zmniejszenie zużycia obrzeży kół. W ten sposób przy normalnym zużyciu powierzchni tocznej i mniejszym zużyciu obrzeży kół może dojść do zwiększenia parametru $\mathrm{q}_{\mathrm{R}}$.

\section{PARAMETR $q_{R} W$ PRZEPISACH TSI DLA WAGONÓW TOWAROWYCH, LOKOMO- TYW ORAZ TABORU PASAŻERSKIEGO}

Parametr stromości obrzeżą $\mathrm{q}_{\mathrm{R}} \mathrm{W}$ przepisach TSI dla wagonów towarowych [17] oraz dla lokomotyw i taboru pasażerskiego [18] w trakcie eksploatacji jest przedstawiony $\mathrm{w}$ tabeli 1 . Parametr ten wraz $\mathrm{z}$ innymi parametrami zestawu kołowego jest przedstawione na rys.9.

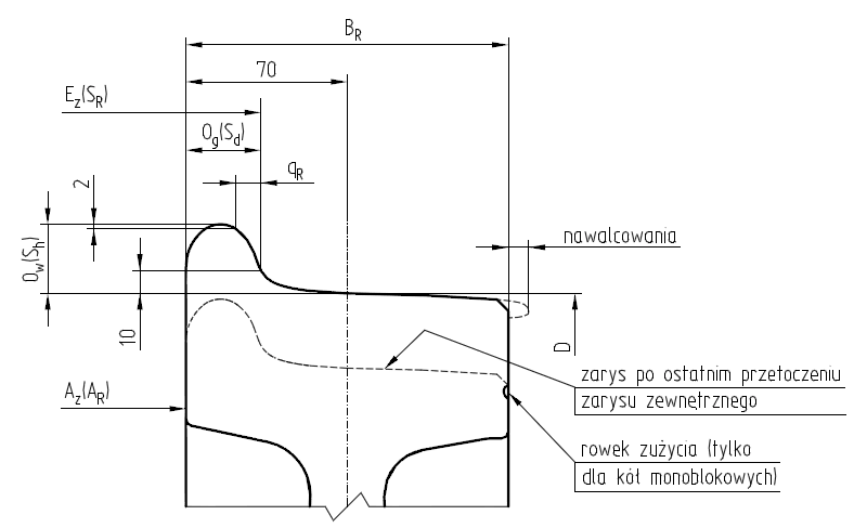

Rys.9. Oznaczenia na rysunku koła zestawu kołowego

\section{Oznaczenia na rysunku:}

$B_{R^{-}}$szerokość zarysu zewnętrznego wieńca koła

Az $\left(A_{R}\right)$ - odległość pomiędzy wewnętrznymi powierzchniami czotowymi wieńców kót

D- średnica toczna koła

$O_{g^{-}}$grubość obrzeża kola

$O_{W}$-wysokość obrzeża koła

$E_{Z}$ szerokość prowadna, odległość pomiędzy zewnętrznymi powierzchniami obrzeży kót, mierzona pomiędzy punktami na obrzeżu, które znajduja się $10 \mathrm{~mm}$ powyżej powierzchni tocznych kót

$q_{R^{-}}$wymiar stromości obrzeża

Analizując kompleksowo podejście przepisów TSI dla wagonów towarowych oraz dla pojazdów trakcyjnych (lokomotyw oraz wagonów osobowych) do parametru $\mathrm{q}_{\mathrm{R}}$ można wyciągnąć wniosek, że przy określeniu kryterium kierowano się bezpieczeństwem jazdy. Jak stwierdzono większe zagrożenie stwarza zmniejszenie parametru stromości obrzeża $\mathrm{q}_{\mathrm{R}}$. Zwiększenie parametru $\mathrm{q}_{\mathrm{R}}$ może ulec zwiększeniu w trakcie eksploatacji, jednak nie stanowi zagrożenia dla bezpieczeństwa jazdy. Zwiększenie tego parametru występuje zarówno w pojazdach trakcyjnych, wagonach osobowych oraz w wagonach towarowych, których właścicielami są 
Wartości parametrów zestawu kołowego $\left(w\right.$ tym $q_{R}$ ) oraz kól podezas eksploatacji pojazdu szynowego zgodnie z parametrami TSI CR WAG

\begin{tabular}{|c|c|c|c|}
\hline Oznaczenie & $\begin{array}{l}\text { Średnica kola } \\
\quad \text { D [mm] }\end{array}$ & $\begin{array}{l}\text { Wartość min. } \\
{[\mathrm{mm}]}\end{array}$ & $\begin{array}{l}\text { Wartość maks. } \\
{[\mathrm{mm}]}\end{array}$ \\
\hline \multirow{3}{*}{$\begin{array}{c}\text { Szerokość prowadna } \mathrm{E}_{\mathrm{z}}\left(\mathrm{S}_{\mathrm{R}}\right) \\
\mathrm{E}_{\mathrm{z}}=\mathrm{A}_{\mathrm{z}}+\mathrm{O}_{\mathrm{g}, \text { lewe }}+\mathrm{O}_{\mathrm{g} \text {,prawe }} \\
\left(\mathrm{S}_{\mathrm{R}}=\mathrm{A}_{\mathrm{R}}+\mathrm{S}_{\mathrm{d} \text {,lewe }}+\mathrm{S}_{\mathrm{d} \text {,prawe }}\right)\end{array}$} & $330 \leq \mathrm{D} \leq 760$ & 1415 & 1426 \\
\hline & $760<\mathrm{D} \leq 840$ & 1412 & 1426 \\
\hline & $\mathrm{D}>840$ & 1410 & 1426 \\
\hline \multirow{3}{*}{$\begin{array}{l}\text { Odległość pomiędzy wewnętrznymi powierzch- } \\
\text { niami wieńca koła } A_{z}\left(A_{R}\right)\end{array}$} & $330 \leq \mathrm{D} \leq 760$ & 1359 & 1363 \\
\hline & $760<\mathrm{D} \leq 840$ & 1358 & 1363 \\
\hline & $\mathrm{D}>840$ & 1357 & 1363 \\
\hline $\begin{array}{c}\text { Szerokość obręczy } B_{R} \\
\text { (max nawalcowanie } 5 \mathrm{~mm} \text { ) }\end{array}$ & $\mathrm{D} \geq 330$ & 133 & 140 \\
\hline \multirow{3}{*}{ Grubość obrzeża $\mathrm{O}_{\mathrm{g}}\left(\mathrm{S}_{\mathrm{d}}\right)$} & $330 \leq \mathrm{D} \leq 760$ & 27,5 & 33 \\
\hline & $760<\mathrm{D} \leq 840$ & 25 & 33 \\
\hline & $\mathrm{D}>840$ & 22 & 33 \\
\hline \multirow{3}{*}{ Wysokość obrzeża $\mathrm{O}_{\mathrm{w}}\left(\mathrm{S}_{\mathrm{h}}\right)$} & $330 \leq \mathrm{D} \leq 630$ & 31,5 & 36 \\
\hline & $630<\mathrm{D} \leq 760$ & 29,5 & 36 \\
\hline & $\mathrm{D}>760$ & 27,5 & 36 \\
\hline Stromość obrzeża $q_{R}$ & $\mathrm{D} \geq 330$ & 6,5 & - \\
\hline
\end{tabular}

różni przewoźnicy krajowi i zagraniczni. Wartość $\mathrm{q}_{\mathrm{R}}$ nie jest równoznaczna z kątem pochylenia obrzeża. Kąt pochylenia obrzeża należy mierzyć w sposób odrębny. Tak więc przetaczanie (reprofilacja) wieńców zewnętrznych wieńców kół $\mathrm{z}$ powodu przekroczenia wymiaru $\mathrm{q}_{\mathrm{R}}$ (ustalonej górnej wartości przez wewnętrzne przepisy) jest nieuzasadnione i prowadzi do strat ekonomicznych taboru. Należy wziąć pod uwagę, że zużycie $1 \mathrm{~mm}$ obrzeża jest równoważne $2,5 \mathrm{~mm}$ zużyciu na powierzchni tocznej. Nawet gdyby stosować toczenie ekonomiczne zgodnie $\mathrm{z}$ norma

1.EN 17315 -S1002 / h28 / e32 / 6,7\% - dla grubości obrzeża $32 \mathrm{~mm}$,

2.EN 17315 - S1002 / h28 / e31,5 / 6,7\% - dla grubości obrzeża $31,5 \mathrm{~mm}$,

3.EN 17315 - S1002 / h28 / e31 / 677\% - dla grubości obrzeża $31 \mathrm{~mm}$,

4.EN 17315 - S1002 / h28 / e30,5 / 6,7\% - dla grubości obrzeża $30,5 \mathrm{~mm}$,

5.EN 17315 - S1002 / h28 / e30 / 6,7\% - dla grubości obrzeża $30 \mathrm{~mm}$,

6.EN 17315 - S1002 / h28 / e29,5 / 6,7\% - dla grubości obrzeża $29,5 \mathrm{~mm}$,

7.EN 17315 - S1002 / h28 / e29 / 6,7\% - dla grubości obrzeża $29 \mathrm{~mm}$,

8. EN 17315 - S1002 / h28 / e28,5 / 6,7\% - dla grubości obrzeża $28,5 \mathrm{~mm}$. to jeśli nie jest to uzasadnione, prowadzi do strat materiałowych.

Celem działalności przewozowej jest prowadzić ją tak, aby reprofilację (,przetoczenie obrzeży”) prowadzić możliwie jak najrzadziej oraz stosować toczenie ekonomiczne $\mathrm{i}$ to tylko wtedy, kiedy jest to technicznie uzasadnione. Uzasadnieniem takim jest przypadek, kiedy przynajmniej jeden $\mathrm{z}$ parametrów lub grupa parametrów, wymienionych $\mathrm{w}$ tabeli 1 osiagnęła dopuszczalne wartości. Zwraca się uwagę na fakt, że użytkownik podejmuje takie decyzje w oparciu o DSU danego pojazdu. Im precyzyjniejsze są zapisy w DSU danego pojazdu przewoźnik może podejmować racjonalniejsze decyzje, dotyczące przetaczania. Przetaczanie wieńców kół, które odbywa się w oparciu o źle zrozumiane kryteria bezpieczeństwa prowadzi tylko do strat materiałowych i obniża konkurencyjność zespołów trakcyjnych na rynku przewozowym.

Przedstawiona wartość wymiaru stromości obrzeża $\mathrm{q}_{\mathrm{R}}=6,5 \mathrm{~mm}$ obowiązuje dla pojazdów szynowych, kursujących po torze normalnym, o prześwicie 1435 $\mathrm{mm}$. W przypadku toru o prześwicie $1000 \mathrm{~mm}$, okazuje się że wymiarem obowiązującym jest $\mathrm{q}_{\mathrm{R}}=3,5 \mathrm{~mm}$, jak wynika $\mathrm{z}$ analiz przeprowadzonych na kolejach szwajcarskich SBB [2]. Kolej szwajcarska wykonała pomiarów z udziałem około 200 pojazdów z 1500 zarysami zewnętrznymi kół i 100 rozjazdów (zwrotnic) z około 1000 wycinkami zarysu zewnętrznego (profilu). 
5. WPLYW MNIEJSZEJ WARTOŚCI $q_{R}$ NA BEZPIECZEŃŚTWO JAZDY W WARUNKACH QUASI-STATYCZNYCH

Mniejsza wartość $\mathrm{q}_{\mathrm{R}}$ zbliżona do wartości 6,5 mm prowadzi do zwiększenia kąta pochylenia obrzeża $\gamma$ do $77^{\circ}$ co może świadczyć o większym kącie pochylenia obrzeża od $70^{\circ}$, a to z kolei zwiększa współczynnik wykolejania zgodnie ze wzorem:

$$
\frac{Y}{Q}=\frac{\operatorname{tg} \gamma-\mu}{1+\mu \cdot \operatorname{tg} \gamma}
$$

gdzie:

Y- siła poprzeczna działająca w kierunku poprzecznym na koło

Q- rzeczywista siła pionowego nacisku na szynę, wywierana prze koło pojazdu.

Po wstawieniu do wzoru (1) kąta $\gamma=77$ ? oraz $\mu=0,36$ do wzoru (1) otrzymuje się:

$$
\frac{Y}{Q}=\frac{\operatorname{tg} 77^{0}-0,36}{1+0,36 \cdot \operatorname{tg} 77^{0}}=1,55
$$

Przykłady zużytych profili ze stromością obrzeża $\mathrm{q}_{\mathrm{R}}=6,5 \mathrm{~mm}$ oraz powiększonym kątem pochylenia obrzeża $\gamma=77^{0}$ są przedstawione na rys. 10 oraz rys.11.

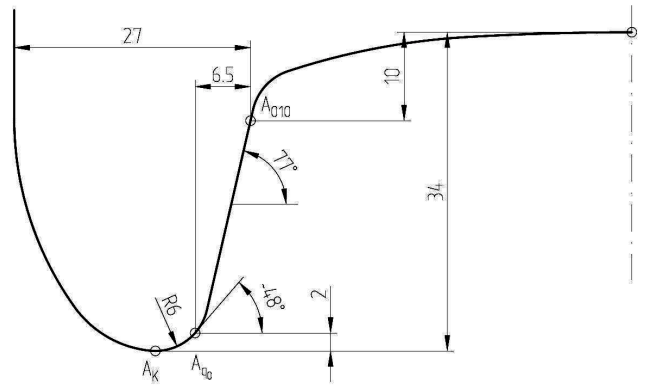

Rys.10. Profil zużyty z $\mathrm{q}_{\mathrm{R}}=6,5 \mathrm{~mm}$ (tzw. strome obrzeże-niem. „steiler Spurkranz”) wg [13]

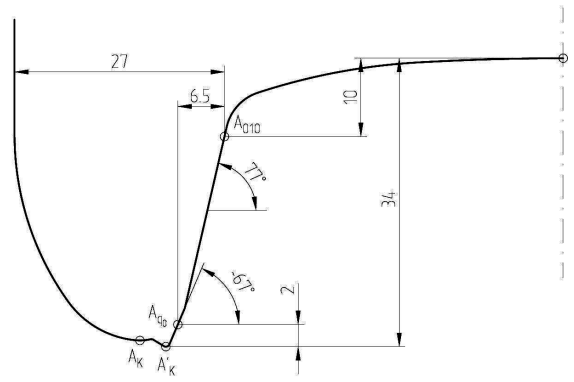

Rys.11. Profil zużyty z z q $=6,5 \mathrm{~mm}$ ( tzw. ostrym obrzeżem „niem. scharfer Spurkranz”) wg [13]

6. WPLYW WIĘKSZEJ WARTOŚCI $q_{R}$ NA BEZPIECZEŃŚTWO JAZDY W WARUNKACH QUASI-STATYCZNYCH

Wraz ze wzrostem wartości $\mathrm{q}_{\mathrm{R}}$ można spodziewać się zmniejszenia wartości kąta pochylenia obrzeża do $\gamma=60$ ? Wartość ta jednak jest uwzględnio- na przy homologacji pojazdów w normie europejskiej PN-EN 14363:2007 [9] zgodnie ze wzorem

$$
\frac{Y}{Q} \leq 0,8
$$

Przyjmując współczynnik tarcia $\mu=0,36$, kąt pochylenia obrzeża $\gamma$ można wyznaczyć z przekształconego wzoru (1):

$$
\begin{gathered}
\gamma=\operatorname{arctg} \frac{\frac{Y}{Q}+\mu}{1-\frac{Y}{Q} \cdot \mu} \\
\gamma=\operatorname{arct} \frac{0,8+0,36}{1-0,8 \cdot 0,36}=58,45^{\circ} \cong 60^{\circ}
\end{gathered}
$$

Zmniejszenie to nawet do kąta pochylenia obrzeża $60^{\circ}$ nie może być więc przyczyną zagrożenia eksploatacyjnego, skoro taki warunek koła $\mathrm{z}$ profilem zużytym dla kąta pochylenia obrzeża $\gamma=60$ ? jest badany podczas homologacji pojazdów. Z kolei należy wziąć pod uwagę, że zgodnie z przepisami D1 (załącznik 14) [16] na torach klasy 3,4 i 5 oraz na torach bocznicowych najmniejszy dopuszczalny kąt pochylenia główki szyny wynosi 55? (w przypadku zużycia szyny), co jest pokazane na rys. 12 .

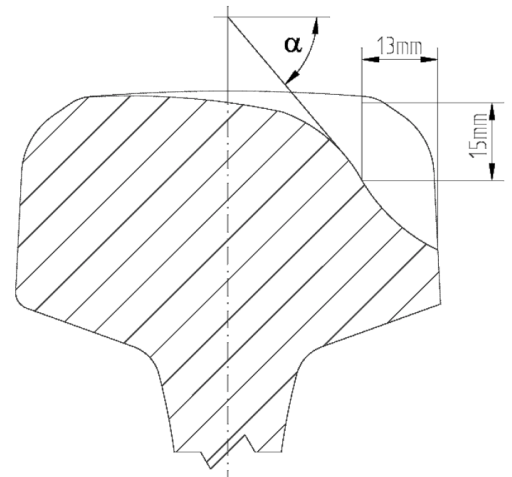

Rys.12. Profil maksymalnie zużytej główki szyny typu UIC 60 lub UIC 49 z kątem pochylenia $\alpha=55^{\circ}$

W przypadku mniejszego kąta pochylenia główki szyny i współpracy z kołem o większym kącie pochylenia obrzeża, decydującym jest mniejszy kąt pochylenia, czyli w tym przypadku kąt pochylenia zużytej szyny. Wskaźnik wykolejenia (wskaźnik przed wykolejeniem) wynosi w takim przypadku zgodnie ze wzorem (1):

$$
\frac{Y}{Q}=\frac{\operatorname{tg} 55^{\circ}-0,36}{1+0,36 \cdot \operatorname{tg} 55^{\circ}}=0,70
$$

W skrajnym przypadku, gdy współczynnik tarcia wynosi $\mu=0,45$ wskaźnik wykolejenia wy-nosi:

$$
\frac{Y}{Q}=\frac{\operatorname{tg} 55^{0}-0,45}{1+0,45 \cdot \operatorname{tg} 55^{0}} \approx 0,60
$$


W takim przypadku jednak nie uwzględnia się pochylenia rampy przechyłkowej oraz wichrowatości własnej toru.

Spadek wskaźnika wykolejenia do wartości 0,8 z tytułu ewentualnego powiększenia parametru stromości obrzeża $\mathrm{q}_{\mathrm{R}}$ nie ma więc wpływu na znaczące obniżenie bezpieczeństwa przed wykolejeniem.

W przypadku przejazdu pojazdu przez zwrotnice kryterium Nadala przyjmuje wartość:

$$
\frac{Y}{Q} \leq 0,4
$$

Przyjmując następujące dane: kąt pochylenia obrzeża $\gamma=40$ ? oraz współczynnik tarcia między kołem a szyna, wynoszący $\mu=0,36$ i wstawiając do wzoru (1) otrzymuje się:

$$
\frac{Y}{Q}=\frac{\operatorname{tg} 40^{0}-0,36}{1+0,36 \cdot \operatorname{tg} 40^{0}}=0,36 \approx 0,4
$$

Dokładna wartość wskaźnika wykolejenia wynosi 0,4 dla współczynnika tarcia między kołem i szyną $\mu=0,32$ :

$$
\frac{Y}{Q}=\frac{\operatorname{tg} 40^{0}-0,32}{1+0,32 \cdot \operatorname{tg} 40^{0}}=0,40 \approx 0,4
$$

Mechanizm zachowania koła zestawu kołowego podczas przejazdu przez zwrotnicę jest przedstawiony na rys. 13.

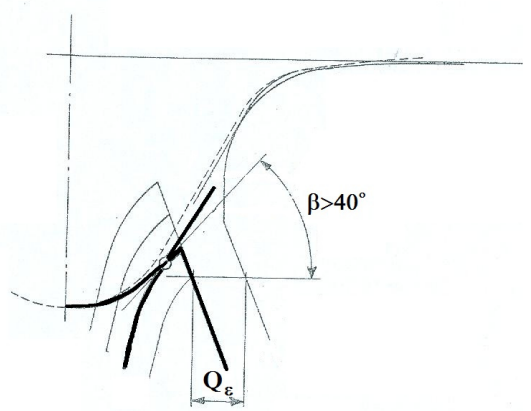

Rys.13. Kontakt obrzeża koła z iglicą zwrotnicy wg [13]

\section{WNIOSKI}

Z punktu widzenia eksploatacyjnego niebezpieczne jest zmniejszenie wymiaru $\mathrm{q}_{\mathrm{R}}$, aniżeli jego zwiększenie. Zwiększenie wymiaru $\mathrm{q}_{\mathrm{R}}$ do wartości 13 lub $14 \mathrm{~mm}$ może świadczyć o łagodniejszym kącie pochylenia obrzeża, co może się zdarzać w eksploatacji, nie powodując jeszcze zagrożenia bezpieczeństwa eksploatacyjnego, zwłaszcza przy przejeździe przez tory wichrowate. Natomiast zmniejszenie tego wymiaru poniżej przyjętego kryterium tzn. $\mathrm{q}_{\mathrm{R}}=6,5 \mathrm{~mm}$ powoduje wprawdzie zwiększenie kąta pochylenia obrzeża do $80^{\circ}$, a tym samym do zwiększenia bezpieczeństwa przejazdu przez tory wichrowate, ale zmniejsza bezpieczeństwo przejazdu przez zwrotnice oraz krzyżownice toru. W związku z powyższym eksploatacja zespołów trakcyjnych, lokomotyw oraz wagonów towarowych, gdzie taki wymiar stwierdzono $\left(\mathrm{q}_{\mathrm{R}} \mathrm{O}\right.$ wartości $13 \mathrm{~mm}$ lub $14 \mathrm{~mm}$ ), może odbywać się dalej. Niniejsza analiza została wykonana $\mathrm{w}$ oparciu o założenie, że inne parametry charakteryzujące zarys zewnętrzny wieńca koła nie zostały przekroczone $\mathrm{z}$ punktu widzenia obowiązujących kryteriów. Czynnikami, które powodują wzrost parametru $\mathrm{q}_{\mathrm{R}}$ ponad wartość obowiązującą do stanu nowego są: jazda pojazdu w przeważającej części trasy po odcinkach prostych toru, urządzenia do smarowania obrzeży, urządzania aktywnego np. sprzęg międzywózkowy i pasywnego sterowania radialnego np. luzy wzdłużne w prowadzeniu kół zestawów kołowych, powodujących zmniejszenie sił prowadzących zestaw kołowy i ułatwiających wpisywanie się zestawów w łuki torów oraz zmniejszenie kątów nabiegania kół zestawu kołowego na szynę, stosowania urządzeń stacjonarnych smarujących szyny na łukach toru itp.

\section{LITERATURA}

[1] Müller R.: Aktuelle Probleme der Berührgeometrie Rad/Schiene. ZEVrail Glasers Annalen 127 Nr.10.2003

[2] Ritscher U.: Entgleisungssicherheit: Untersuchungen im Weichenbereich. Eisenbahn-ingenieur 01.2008.

[3] PN-EN 13103+A2:2012: Kolejnictwo. Zestawy kolowe $i$ wózki. Osie zestawów kolowych .Zasady konstrukcji.

[4] PN-EN 13104+A2:2012: Kolejnictwo. Zestawy kołowe $i$ wózki. Osie zestawów kołowych napędnych. Zasady konstrukcji.

[5] PN-EN 13260+A1:2011: Kolejnictwo. Zestawy kolowe $i$ wózki. Zestawy kołowe. Wymagania dotyczace wyrobu.

[6] PN-EN 13261+A1:2011: Kolejnictwo. Zestawy kolowe $i$ wózki. Osie. Wymagania dotyczqce wyrobu.

[7] PN-EN 13262+A2:2011: Kolejnictwo. Zestawy kolowe $i$ wózki. Kola. Wymagania dotyczace wyrobu.

[8] PN-EN 13715+A1:2011:Kolejnictwo. Zestawy kolowe i wózki. Koła. Zarysy zewnętrzne wieńców kót.

[9] PN-EN 14363:2007: Badania wtaściwości dynamicznych przed dopuszczeniem pojazdów szynowych. Badanie właściwości biegowych i próby stacjonarne

[10]PN-EN 15313:2010: Kolejnictwo. Wymagania eksploatacyjne dotyczqce obstugi zestawów kolowych. Utrzymanie zestawów kolowych pojazdów w eksploatacji $i$ wytaczonych z eksploatacji.

[11]Karta UIC 510-2: Pojazdy doczepne. Warunki dla stosowania kót o różnych średnicach $w$ uktadach biegowych różnego typu. 4-te wydanie z października 2002 do kwietnia 2004.

[12]Raport ORE/ERRI : Frage C70/RE/D. Gegenseitig zulässige Abnutzungsprofile von Radreifen und Weichenanlagen. Umfragebericht. Utrecht, czerwiec 1964

[13]Raport ORE/ERRI: Frage C70/RP1/D. Gegenseitig zulässige Abnutzungsprofile von Radreifen und Weichenanlagen. Utrecht, kwiecień 1969

[14]Raport ORE/ERRI :Question ORE B12.Standarisation des wagons. Standarisation des bogies du genre Y25a essieux orientables. Utrecht, kwiecień 1992.

[15]Instrukcja pomiarów geometrycznych zestawów kotowych trakcyjnych PKP. Warszawa. Mt 11. Dyrekcja Generalna PKP 1995. 
[16]Przepisy D1. Warunki techniczne utrzymania nawierzchni na linach kolejowych. Załacznik do Uchwaty nr 155 Zarzqdu PKP Polskie Linie Kolejowe S.A. z dnia 6 czerwca 2002. PKP Polskie Linie Kolejowe S.A. Warszawa 2002.

[17]Przepisy CR TSI WAG ,Wagony towarowe. Przyjęte decyzja Komisji Europejskiej 2006/86/2009/107. Nowa wersja 2012.
[18] Przepisy TSI . DECYZJA KOMISJI z dnia 26 kwietnia 2011 w sprawie technicznej specyfikacji interoperacyjności odnoszacej się do podsystemu „Tabor-lokomotywy i tabor pasażerski” $w$ transeuropejskim systemie kolei konwencjonalnych"

[19] Przepisy DB: Eisenbahn-Bau und Betriebsverordnung (EBO). Ważne od 28.05.1967 